\title{
Serous cystadenocarcinoma of pancreas
}

INSERM

\section{Source}

INSERM. (1999). Orphanet: an online rare disease and orphan drug data base. Serous cystadenocarcinoma of pancreas. ORPHA:424073

A very rare, malignant, epithelial tumor of the pancreas composed of cystic structures lined by glycogen-rich clear cells, associated with local invasiveness often involving the spleen, duodenum and/or stomach and metastatic spread to the liver, peritoneum and/or lymph nodes. Presenting symptoms are variable and usually non-specific and include abdominal and/or flank pain, palpable abdominal mass, upper gastrointestinal bleeding, jaundice or abnormal serum liver enzymes, vomiting, anorexia and/or weight loss. 